\title{
Effects of particulate matter on inflammatory markers in the general adult population
}

\author{
Dai-Hua Tsai ${ }^{1,2}$, Nadia Amyai ${ }^{3}$, Pedro Marques-Vidal', Jia-Lin Wang ${ }^{2}$, Michael Riediker ${ }^{4}$, Vincent Mooser ${ }^{5}$,
} Fred Paccaud ${ }^{1}$, Gerard Waeber ${ }^{3}$, Peter Vollenweider ${ }^{3}$ and Murielle Bochud ${ }^{1 *}$

\begin{abstract}
Background: Particulate air pollution is associated with increased risk of cardiovascular disease and stroke. Although the precise mechanisms underlying this association are still unclear, the induction of systemic inflammation following particle inhalation represents a plausible mechanistic pathway.

Methods: We used baseline data from the CoLaus Study including 6183 adult participants residing in Lausanne, Switzerland. We analyzed the association of short-term exposure to $\mathrm{PM}_{10}$ (on the day of examination visit) with continuous circulating serum levels of high-sensitive C-reactive protein (hs-CRP), interleukin 1-beta (IL-1 $\beta$ ), interleukin 6 (IL-6), and tumor-necrosis-factor alpha (TNF-a) by robust linear regressions, controlling for potential confounding factors and assessing effect modification.

Results: In adjusted analyses, for every $10 \mu \mathrm{g} / \mathrm{m}^{3}$ elevation in $\mathrm{PM}_{10,} \mathrm{IL}-1 ß$ increased by 0.034 (95\% confidence interval, $0.007-0.060) \mathrm{pg} / \mathrm{mL}$, IL-6 by $0.036(0.015-0.057) \mathrm{pg} / \mathrm{mL}$, and TNF-a by $0.024(0.013-0.035) \mathrm{pg} / \mathrm{mL}$, whereas no significant association was found with hs-CRP levels.

Conclusions: Short-term exposure to $\mathrm{PM}_{10}$ was positively associated with higher levels of circulating IL-1ß, IL-6 and TNF-a in the adult general population. This positive association suggests a link between air pollution and cardiovascular risk, although further studies are needed to clarify the mechanistic pathway linking $\mathrm{PM}_{10}$ to cardiovascular risk.
\end{abstract}

Keywords: High-sensitive C-reactive protein (hs-CRP), Interleukin 1-beta (IL-1ß), Interleukin 6 (IL-6), Tumor-necrosis-factor alpha (TNF-a), Air pollution

\section{Background}

Variations in short-term exposure to particulate matters (PM) have been repeatedly associated with daily all-cause mortality [1]. In the APHENA study, the combined effect of a $10-\mu \mathrm{g} / \mathrm{m}^{3}$ elevation in ambient particulate matters smaller than $10 \mu \mathrm{m}\left(\mathrm{PM}_{10}\right)$ on all-cause mortality ranged from $0.2 \%$ to $0.6 \%$ [2]. Further, the exposure of older people to $\mathrm{PM}_{10}$ was more strongly associated with cardiovascular mortality $(0.47 \%$ to $1.30 \%)$ than with noncardiovascular mortality [2]. It was recently estimated that every $10 \mu \mathrm{g} / \mathrm{m}^{3}$ increase in the daily mean $\mathrm{PM}_{10}$ levels could be associated with a $1.6 \%$ increased incidence of myocardial infarction [3]. Particle-induced inflammation

\footnotetext{
* Correspondence: murielle.bochud@chuv.ch

'Institute of Social and Preventive Medicine (IUMSP), Lausanne University Hospital (CHUV), Biopôle 2, Route de la Corniche 10, CH-1010 Lausanne, Switzerland

Full list of author information is available at the end of the article
}

has been postulated to be one of the important mechanisms for increased cardiovascular risk [1,4]. Experimental in-vitro, in-vivo and controlled human studies suggest that interleukin 6 (IL-6) and tumor-necrosis-factor alpha (TNF- $\alpha$ ) could represent key mediators of the inflammatory response to PM exposure [1,5-7].

The associations of short-term exposure to ambient PM with circulating inflammatory markers have been inconsistent in studies including specific subgroups so far. Short-term exposure to PM has been associated with elevated C-reactive protein (CRP) in some [8-12], but not in all [13-15] studies. Short-term exposure to PM has also been associated with elevated IL-6 in some susceptible subjects $[16,17]$ and with elevated TNF- $\alpha$ in healthy children [8].

The results of large-scale population-based studies have also been largely inconsistent. Short-term exposure to PM has been associated with elevated fibrinogen and 
CRP in some [18-20], but not in other [21-23] studies. Similarly, an association with elevated white blood cell counts was found in some [18], but not in other [22] studies. Hence, the epidemiological evidence linking short-term exposure to ambient PM and systemic inflammation in the general population is limited. So far, large-scale population-based studies have not explored important inflammatory markers such as IL- 6 or TNF- $\alpha$. We therefore analyzed the associations between shortterm exposure to ambient $\mathrm{PM}_{10}$ and circulating levels of several inflammatory markers, namely high-sensitive CRP (hs-CRP), IL-1 $\beta$, IL-6, and TNF- $\alpha$ in the population-based CoLaus study.

\section{Results}

The distributions of $\mathrm{PM}_{10}$, air temperature, relative humidity, and pressure by season are shown in Figure 1, with extreme values (minimum and maximum) and three quartile values $(25,50$ and $75 \%)$.

Participants' characteristics are presented in Table 1 . About $53 \%$ were women and $57 \%$ were older than 55 years. Women tended to have higher hs-CRP and IL$1 \beta$ than men ( $p$-value $=0.01$ and $<0.01$, respectively), but significantly lower IL-6 and TNF- $\alpha$ (p-value $<0.01$ ).
People aged 55 years and over had higher hs-CRP, IL-6 and TNF- $\alpha$, compared with younger people. Similarly, overweight and obese participants, as well as those with hypertension, had higher hs-CRP, IL- 6 and TNF- $\alpha$ levels, compared to their respective normal weight and normotensive controls. Smokers tended to have higher levels of all inflammatory markers. Diabetic participants and people who consume alcohol had higher values of hsCRP, IL-6, and TNF- $\alpha$. Sensitivity analyses led to similar results (Additional file: Table S1).

$\mathrm{PM}_{10}$ levels averaged over 24 hours were significantly and positively associated with continuous IL-1 $\beta$, IL-6 and TNF- $\alpha$ levels in the whole study population both in unadjusted and adjusted analyses (Table 2). Except for IL-1 $\beta$, sensitivity analyses led to similar results for IL-6 and TNF- $\alpha$ (Additional file: Table S2). Secondary analyses using different time windows also led to similar conclusions (Figure 2). We found similar associations of $\mathrm{PM}_{10}$ with inflammatory markers with 1 to 6 days lag (Table 3). Sensitivity analyses led to similar results for IL- 6 and TNF- $\alpha$, but not for IL- $1 \beta$ (Additional file: Table S3). Whereas the association of short term exposure to $\mathrm{PM}_{10}$ tended to decrease with increasing lag for TNF- $\alpha$, no such tendency was observed for IL-1 $\beta$ or IL-6.
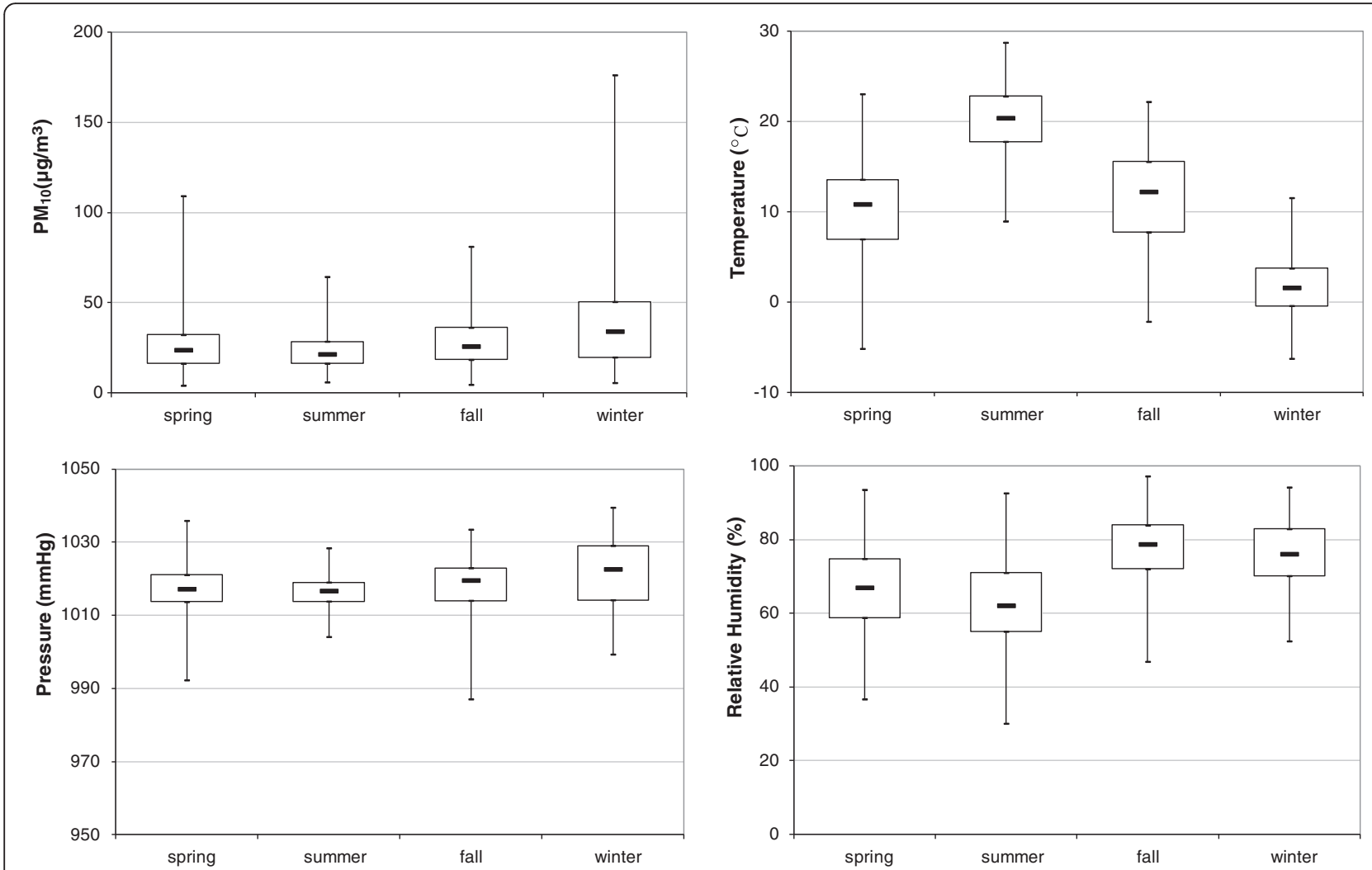

Figure 1 Box plot of particular matter concentrations and selected meteorological data measured at the César Roux station during the period of the study from 2003 to 2006 . The median, $50^{\text {th }}$, and $75^{\text {th }}$ percentiles are given in the box plot. Whiskers show the maximum and minimum values. 
Table 1 Levels of inflammatory markers overall and by selected subgroups

\begin{tabular}{|c|c|c|c|c|c|c|c|c|c|}
\hline & \multirow[b]{2}{*}{ Subjects [n] } & \multicolumn{2}{|c|}{ hs-CRP ( $\mu \mathrm{g} / \mathrm{mL})$} & \multicolumn{2}{|r|}{$\mathrm{IL}-1 \beta(\mathrm{pg} / \mathrm{mL})$} & \multicolumn{2}{|r|}{ IL-6 (pg/mL) } & \multicolumn{2}{|c|}{ TNF-a (pg/mL) } \\
\hline & & $\mathbf{N}$ & Median (P25-P75) & $\mathbf{N}$ & Median (P25-P75) & $\mathbf{N}$ & Median (P25-P75) & $\mathbf{N}$ & Median (P25-P75) \\
\hline All subjects & 6183 & 6171 & $1.30(0.60-2.70)$ & 6083 & $0.39(0.10-1.74)$ & 6077 & $1.32(0.58-3.21)$ & 6077 & $2.87(1.79-4.50)$ \\
\hline \multicolumn{10}{|l|}{ Sex } \\
\hline Female & $3251(52.6)$ & 3247 & $1.30(0.60-2.90)$ & 3200 & $0.45(0.10-1.93)$ & 3197 & $1.21(0.53-2.93)$ & 3196 & 2.73(1.71-4.38) \\
\hline Male & $2932(47.4)$ & 2924 & $1.20(0.60-2.60)$ & 2883 & $0.34(0.10-1.52)$ & 2880 & $1.46(0.65-3.53)$ & 2881 & $3.03(1.89-4.62)$ \\
\hline$p$-value & & & 0.01 & & $<0.01$ & & $<0.01$ & & $<0.01$ \\
\hline \multicolumn{10}{|l|}{ Age (Years) } \\
\hline$<55$ & $3506(56.7)$ & 3500 & $1.00(0.50-2.40)$ & 3447 & $0.49(0.10-2.13)$ & 3444 & $1.20(0.52-3.16)$ & 3442 & $2.69(1.68-4.26)$ \\
\hline$>=55$ & 2677(43.3) & 2671 & $1.60(0.80-3.20)$ & 2636 & $0.29(0.10-1.32)$ & 2633 & $1.46(0.68-3.27)$ & 2635 & $3.13(1.99-4.82)$ \\
\hline$p$-value & & & $<0.01$ & & $<0.01$ & & $<0.01$ & & $<0.01$ \\
\hline \multicolumn{10}{|l|}{ BMI } \\
\hline$<25$ & $2970(48.0)$ & 2963 & $0.80(0.40-1.70)$ & 2923 & $0.46(0.10-1.99)$ & 2921 & $1.15(0.49-3.10)$ & 2920 & $2.68(1.68-4.20)$ \\
\hline$>=25$ & $3213(52.0)$ & 3208 & $1.90(0.90-3.80)$ & 3160 & $0.35(0.10-1.52)$ & 3156 & $1.46(0.69-3.34)$ & 3157 & $3.09(1.90-4.79)$ \\
\hline p-value & & & $<0.01$ & & $<0.01$ & & $<0.01$ & & $<0.01$ \\
\hline \multicolumn{10}{|l|}{ Smoking } \\
\hline No & $4510(72.9)$ & 4506 & $1.20(0.60-2.70)$ & 4452 & $0.39(0.10-1.68)$ & 4449 & $1.22(0.54-3.00)$ & 4448 & $2.84(1.78-4.46)$ \\
\hline Yes & 1673(27.1) & 1665 & $1.40(0.70-2.90)$ & 1631 & $0.42(0.10-1.99)$ & 1628 & $1.57(0.75-3.76)$ & 1629 & $2.99(1.86-4.78)$ \\
\hline$p$-value & & & $<0.01$ & & 0.07 & & $<0.01$ & & $<0.01$ \\
\hline \multicolumn{10}{|l|}{ Diabetes } \\
\hline No & 5764(93.2) & 5764 & $1.20(0.60-2.60)$ & 5680 & $0.41(0.10-1.79)$ & 5675 & $1.29(0.57-3.16)$ & 5674 & $2.84(1.78-4.46)$ \\
\hline Yes & $407(6.8)$ & 407 & $2.10(1.00-4.50)$ & 402 & $0.15(0.10-0.97)$ & 401 & $1.87(0.90-3.78)$ & 402 & $3.52(2.20-5.35)$ \\
\hline$p$-value & & & $<0.01$ & & $<0.01$ & & $<0.01$ & & $<0.01$ \\
\hline \multicolumn{10}{|c|}{ Hypertension } \\
\hline No & 3960(47.9) & 3953 & $1.10(0.50-2.30)$ & 3895 & $0.46(0.10-1.95)$ & 3893 & $1.19(0.52-3.08)$ & 3891 & $2.72(1.69-4.29)$ \\
\hline Yes & 2223(52.1) & 2218 & $1.80(0.90-3.60)$ & 2188 & $0.30(0.10-1.42)$ & 2184 & $1.54(0.71-3.45)$ & 2186 & $3.17(2.04-4.92)$ \\
\hline$p$-value & & & $<0.01$ & & $<0.01$ & & $<0.01$ & & $<0.01$ \\
\hline \multicolumn{10}{|l|}{ Alcohol } \\
\hline No & 4613(74.6) & 4606 & $1.20(0.60-2.70)$ & 4541 & $0.42(0.10-1.83)$ & 4536 & $1.27(0.55-3.10)$ & 4536 & $2.84(1.78-4.50)$ \\
\hline Yes & $1567(25.4)$ & 1567 & $1.40(0.70-2.70)$ & 1540 & $0.34(0.10-1.58)$ & 1539 & $1.48(0.66-3.54)$ & 1539 & $2.96(1.84-4.60)$ \\
\hline p-value & & & $<0.01$ & & $<0.01$ & & $<0.01$ & & 0.11 \\
\hline
\end{tabular}

Note: by Wilcoxon rank sum test.

The associations of $\mathrm{PM}_{10}$ with inflammatory markers in different subgroups are presented in Table 4. $\mathrm{PM}_{10}$ was significantly associated with IL- $1 \beta$, IL- 6 and TNF- $\alpha$ in men, but only with IL- 6 and TNF- $\alpha$ in women. However, there was no significant statistical interaction between $\mathrm{PM}_{10}$ and sex. For IL- $1 \beta$, IL- 6 and TNF- $\alpha$, the associations tended to be stronger in younger people. $\mathrm{PM}_{10}$ was significantly associated with IL- 6 and TNF- $\alpha$ in the healthy group and also in the "non-healthy" group, although the statistical interaction between healthy status and $\mathrm{PM}_{10}$ was not significant. In addition, $\mathrm{PM}_{10}$ was significantly associated with IL-6 and TNF- $\alpha$ in the

Table 2 Change (and $95 \% \mathrm{Cl}$ ) in inflammatory markers associated with a $10 \mu \mathrm{g} / \mathrm{m}^{3}$ change in ambient $24 \mathrm{~h}$ average $\mathrm{PM}_{10}$ concentration

\begin{tabular}{lcccc}
\hline & Crude effects $\mathbf{( 9 5} \% \mathbf{C l})$ & p-value & Adjusted effects $(\mathbf{9 5} \% \mathbf{C l})^{\text {a }}$ & p-value \\
\hline hs-CRP $(\boldsymbol{\mu g} / \mathbf{m L})$ & $0.004(-0.015,0.016)$ & 0.961 & $-0.002(-0.017,0.013)$ & 0.820 \\
IL-1 $\boldsymbol{\beta}(\mathbf{p g} / \mathbf{m L})$ & $0.040(0.016,0.065)$ & 0.001 & $0.034(0.007,0.060)$ & 0.014 \\
IL-6 $(\mathbf{p g} / \mathbf{m L})$ & $0.026(0.006,0.045)$ & 0.010 & $0.036(0.015,0.057)$ & 0.001 \\
TNF- $\mathbf{a}(\mathbf{p g} / \mathbf{m L})$ & $0.015(0.004,0.025)$ & 0.005 & $0.024(0.013,0.035)$ & $<0.001$ \\
\hline
\end{tabular}

$\$$ Covariates included in the model: sex, age, BMl, alcohol consumption, smoking status, education levels, zip code, statin, diabetes, hypertension, season, outdoor air temperature, and outdoor air pressure. Data are coefficients from robust regression models. 


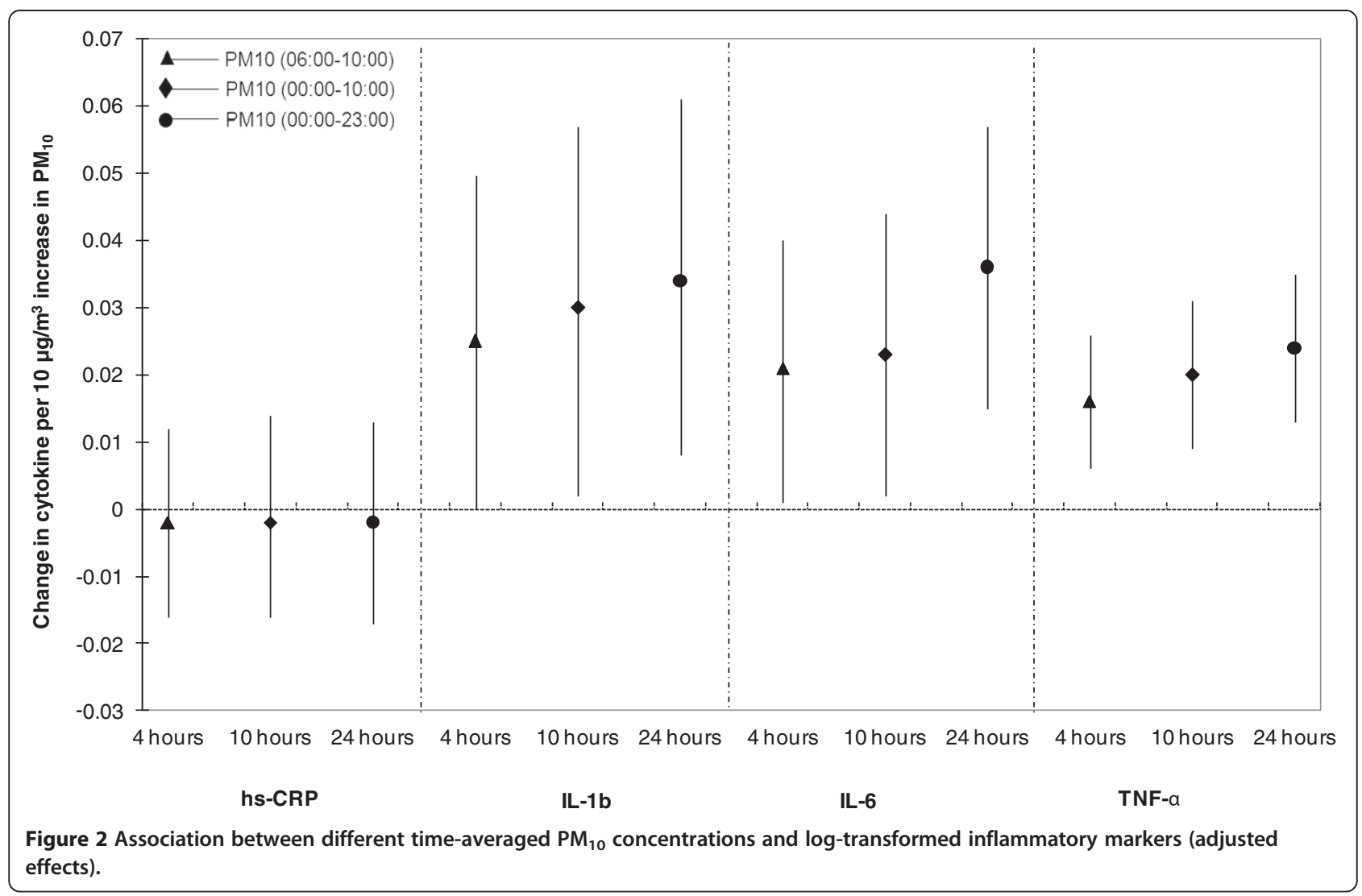

participants who were not on statin therapy. Sensitivity analyses led to similar results for IL- 6 and TNF- $\alpha$, but not for IL-1 $\beta$ (Additional file: Table S4).

\section{Discussion}

In the population-based CoLaus study, short-term exposure to $\mathrm{PM}_{10}$ was associated with circulating levels of IL-1 $\beta$, IL- 6 and TNF- $\alpha$, but not of hs-CRP. Our results are consistent with findings by Ruckerl et al., who showed no association of $\mathrm{PM}_{10}$ with hs-CRP, but a significant positive association of particle number concentration with IL-6 levels in 1003 myocardial infarction (MI) survivors [17]. In several small-sized studies, similar associations were found [24-26]. Furthermore, our results are in line with experimental data. Van Eeden et al. [24] showed that human alveolar macrophages produce TNF- $\alpha$ in a dose-dependent manner when exposed to atmospheric particles. Kido et al. [27] found the lung to be a major source of systemic circulating IL-6 levels in mice exposed to ambient PM. Our study is the first large scale population-based study to show significant positive associations of short-term exposure to $\mathrm{PM}_{10}$ with circulating IL- $1 \beta$, IL- 6 and TNF- $\alpha$ levels, which substantially increases the external validity of previous findings. The relevance of these results is emphasized by the fact that IL- 6 plays a central role in the inflammatory response in the context of cardiovascular disease [5].

Systemic inflammation is known to be associated with cardiovascular morbidity and mortality [1]. Indeed, a number of epidemiological and experimental studies have shown that circulating markers of systemic inflammation and haemostasis are closely associated with the development of fatal and non-fatal MI [28-32]. Inflammation is likely to interfere directly with the blood coagulation pathways leading to hypercoagulation states [33], as well as to increase the probability for a plaque rupture leading to acute coronary events by accentuating atherosclerotic plaque vulnerability [28]. These findings, together with the observation that short-term exposure to higher $\mathrm{PM}_{10}$ levels are associated with the risk of myocardial infarction and acute ischemic stroke [34], suggest that air pollution-induced systemic inflammation may increase cardiovascular risk [3].

Many hypotheses have been proposed to explain the pathophysiological mechanism underlying the link between PM inhalation and systemic inflammation. Exposure of the pulmonary bronchial tree to PM may induce a local inflammatory reaction with the production of specific cytokines from neutrophils, macrophages and $\mathrm{T}$ cells [1]. In vitro studies have shown that human alveolar macrophages exposed to $\mathrm{PM}_{10}$ release numerous 
Table 3 Association of short-term exposure to $24 \mathrm{~h}$ average PM10 with inflammatory markers on the day of examination, and with 1-day to 6-day lags from adjusted robust regression models $\$$

\begin{tabular}{|c|c|c|c|c|c|c|c|c|}
\hline & hs-CRP & $\mathrm{p}$-value & IL-1 $\beta$ & $\mathrm{p}$-value & IL-6 & p-value & TNF-a & $\mathrm{p}$-value \\
\hline \multirow[t]{2}{*}{ Lag 0 (Same day) } & -0.002 & 0.820 & 0.034 & 0.014 & 0.036 & 0.001 & 0.024 & $<0.001$ \\
\hline & $(-0.017,0.013)$ & & $(0.007,0.060)$ & & $(0.015,0.057)$ & & $(0.013,0.035)$ & \\
\hline \multirow[t]{2}{*}{ Lag 1} & 0.001 & 0.854 & 0.034 & 0.011 & 0.035 & 0.001 & 0.022 & $<0.001$ \\
\hline & $(-0.013,0.016)$ & & $(0.008,0.061)$ & & $(0.015,0.056)$ & & $(0.011,0.033)$ & \\
\hline \multirow[t]{2}{*}{ Lag 2} & 0.002 & 0.798 & 0.039 & 0.004 & 0.039 & $<0.001$ & 0.023 & $<0.001$ \\
\hline & $(-0.013,0.017)$ & & $(0.013,0.066)$ & & $(0.019,0.060)$ & & $(0.013,0.034)$ & \\
\hline \multirow[t]{2}{*}{ Lag 3} & -0.001 & 0.944 & 0.037 & 0.006 & 0.040 & $<0.001$ & 0.023 & $<0.001$ \\
\hline & $(-0.015,0.014)$ & & $(0.010,0.063)$ & & $(0.020,0.061)$ & & $(0.012,0.034)$ & \\
\hline \multirow[t]{2}{*}{ Lag 4} & 0.002 & 0.784 & 0.038 & 0.004 & 0.041 & $<0.001$ & 0.022 & $<0.001$ \\
\hline & $(-0.013,0.017)$ & & $(0.012,0.065)$ & & $(0.020,0.061)$ & & $(0.011,0.033)$ & \\
\hline \multirow[t]{2}{*}{ Lag 5} & 0.003 & 0.662 & 0.037 & 0.006 & 0.035 & 0.001 & 0.019 & 0.001 \\
\hline & $(-0.011,0.018)$ & & $(0.010,0.063)$ & & $(0.015,0.055)$ & & $(0.008,0.030)$ & \\
\hline \multirow[t]{2}{*}{ Lag 6} & 0.002 & 0.753 & 0.030 & 0.025 & 0.036 & 0.001 & 0.019 & 0.001 \\
\hline & $(-0.012,0.017)$ & & $(0.004,0.056)$ & & $(0.016,0.056)$ & & $(0.008,0.030)$ & \\
\hline
\end{tabular}

${ }^{\S}$ Adjusted for: sex, age, BMI, alcohol consumption, smoking status, education levels, zip code, statin, diabetes, hypertension, season, outdoor air temperature, and outdoor air pressure.

inflammatory cytokines, including IL-6 and TNF- $\alpha$ $[6,7,24]$. The diffusion of these cytokines in the systemic circulation induces a generalized reaction leading to the inflammation cascade [35]. Recently, a second hypothesis has been proposed, suggesting that inhaled PM and especially $\mathrm{PM}_{2.5}$ directly penetrate into the vascular tree where they interact with endothelial cells and the immune system further activating the inflammation cascade [36].

Table 4 Associations of short-term exposure to $24 \mathrm{~h}$ average $\mathrm{PM}_{10}$ with inflammatory markers, by selected strata

\begin{tabular}{|c|c|c|c|c|c|c|c|c|}
\hline & hs-CRP & p-value & IL-1 $\beta$ & p-value & IL-6 & p-value & TNF- $a$ & p-value \\
\hline \multirow[t]{2}{*}{ Female } & -0.008 & 0.439 & 0.019 & 0.302 & 0.035 & 0.015 & 0.023 & 0.002 \\
\hline & $(-0.028,0.012)$ & & $(-0.017,0.056)$ & & $(0.007,0.063)$ & & $(0.008,0.038)$ & \\
\hline \multirow[t]{2}{*}{ Male } & 0.009 & 0.416 & 0.050 & 0.012 & 0.041 & 0.009 & 0.025 & 0.002 \\
\hline & $(-0.013,0.031)$ & & $(0.011,0.090)$ & & $(0.010,0.071)$ & & $(0.009,0.041)$ & \\
\hline Interaction p-value $\mathrm{e}^{\S}$ & & 0.560 & & 0.376 & & 0.869 & & 0.620 \\
\hline \multirow[t]{2}{*}{ Age $<55$} & -0.007 & 0.511 & 0.037 & 0.047 & 0.048 & 0.001 & 0.027 & $<0.001$ \\
\hline & $(-0.027,0.013)$ & & $(0.0004,0.073)$ & & $(0.020,0.077)$ & & $(0.013,0.042)$ & \\
\hline \multirow[t]{2}{*}{ Age $>=55$} & 0.007 & 0.527 & 0.030 & 0.141 & 0.022 & 0.144 & 0.020 & 0.021 \\
\hline & $(-0.015,0.029)$ & & $(-0.010,0.069)$ & & $(-0.008,0.052)$ & & $(0.003,0.036)$ & \\
\hline Interaction $p$-value ${ }^{\S}$ & & 0.404 & & 0.703 & & 0.105 & & 0.619 \\
\hline \multirow[t]{2}{*}{ Healthy $^{\dagger}$} & 0.025 & 0.151 & 0.038 & 0.250 & 0.062 & 0.022 & 0.035 & 0.009 \\
\hline & $(-0.009,0.058)$ & & $(-0.027,0.103)$ & & $(0.009,0.114)$ & & $(0.009,0.062)$ & \\
\hline \multirow[t]{2}{*}{ Non-healthy ${ }^{\dagger}$} & -0.007 & 0.400 & 0.033 & 0.027 & 0.029 & 0.011 & 0.022 & $<0.001$ \\
\hline & $(-0.024,0.009)$ & & $(0.004,0.062)$ & & $(0.007,0.052)$ & & $(0.010,0.034)$ & \\
\hline Interaction $p$-value $e^{\S}$ & & 0.620 & & 0.708 & & 0.862 & & 0.769 \\
\hline \multirow[t]{2}{*}{ No statins } & -0.002 & 0.806 & 0.027 & 0.064 & 0.036 & 0.002 & 0.024 & $<0.001$ \\
\hline & $(-0.018,0.014)$ & & $(-0.002,0.056)$ & & $(0.013,0.058)$ & & $(0.012,0.036)$ & \\
\hline \multirow[t]{2}{*}{ With statins } & 0.006 & 0.773 & 0.073 & 0.057 & 0.038 & 0.165 & 0.020 & 0.203 \\
\hline & $(-0.036,0.049)$ & & $(-0.002,0.015)$ & & $(-0.016,0.093)$ & & $(-0.011,0.051)$ & \\
\hline Interaction $p$-value $e^{\S}$ & & 0.843 & & 0.372 & & 0.886 & & 0.812 \\
\hline
\end{tabular}

Data are coefficients $(95 \% \mathrm{Cl})$ from robust regression models. Coefficients represent change in cytokine per $10 \mu \mathrm{g} / \mathrm{m}^{3}$ increase in $\mathrm{PM} \mathrm{M}^{\S}{ }^{\S} \mathrm{P}$-value for interaction between the strata variable and $\mathrm{PM}_{10}$ for their effects on the inflammatory marker.

† Sample sizes for healthy and non-healthy are 993 and 5190, respectively. 
We found no association of short-term exposure to $\mathrm{PM}_{10}$ with circulating hs-CRP levels. This is in line with the results of previous population-based studies $[20,21,23]$. The absence of association with hs-CRP might be related to the fact that we only explored short-term exposure, as one study found a positive association of hsCRP with long-term exposure to $\mathrm{PM}_{10}$ [21]. Yet, Hertel at al found short-term exposure to particle number to be associated with hs-CRP in 4000 participants to the population-based Heinz Nixdorf Recall study [20]. CRP production is increased following the hepatic action of IL-6. CRP represents a later marker of inflammation than IL-6, for instance, with a half-life of around 15-19 hours for CRP [37]. This may explain the absence of association with short-term exposure to $\mathrm{PM}_{10}$ in our study.

This study has some limitations which should be acknowledged. This is a cross-sectional analysis using the absolute level of $\mathrm{PM}_{10}$ at a single point in time. Unfortunately, data for $\mathrm{PM}_{2.5}$ was not available in this study. Also, our results only pertain to short-term exposure to $\mathrm{PM}_{10}$. The effects of long-term exposure to $\mathrm{PM}_{10}$ levels could not be assessed because long-term individual-level exposure data are not available. Personal exposures can vary substantially from the levels measured at a central monitoring station. We did not capture differences in long-term exposure due to different exposures to local sources (roads, industrial sources). This is a problem common to large epidemiological studies that, unlike panel studies, cannot equip each subject with personal exposure monitoring devices. To account for variations attributable to spatial differences in participants' place of residence, we included the zip code as a covariate in the models. $\mathrm{PM}_{10}$ is a complex mixture of chemical compounds the behavior of which strongly depends on the atmospheric conditions. Putard et al. reported that the most important compounds to $\mathrm{PM}_{10}$ mass in four Swiss locations (Bern, Zurich, Basel, and Chaumont) were black carbon, organic matter, mineral dust, ammonium, nitrate and sulphate [38]. The studied population is from a single geographical area, and the findings may not be generalisable to other regions or cities. In addition, results for IL$1 \beta$ should be interpreted with caution because $38 \%$ of IL-1 $\beta$ was below the detection limit of the assay. More sensitive assays are therefore needed to reduce the proportion of undetectable values for IL-1 $\beta$ and to provide better estimates of the association of $\mathrm{PM}_{10}$ with circulating IL-1 $\beta$ levels.

\section{Conclusions}

In summary, we found significant independent positive associations of short-term exposure to $\mathrm{PM}_{10}$ with circulating levels of IL- 6 and TNF- $\alpha$ in the adult population of Lausanne. Our findings strongly support the idea that short-term exposure to $\mathrm{PM}_{10}$ is sufficient to induce systemic inflammation on a broad scale in the general population. Even slight increases in the distribution of inflammatory cytokines may represent a substantial health burden at the population level, in particular by increasing cardiovascular morbidity and mortality, although the precise mechanistic pathway linking $\mathrm{PM}_{10}$ to cardiovascular risk has not yet been elucidated. From a public health perspective, the reported association of elevated inflammatory cytokines with short-term exposure to $\mathrm{PM}_{10}$ in a city with relatively clean air such as Lausanne supports the importance of limiting urban air pollution levels.

\section{Methods}

\section{Study population}

All study subjects were participants to the CoLaus study (www.colaus.ch), an ongoing population-based cohort study. The baseline examination was carried out from 2003 to 2006. Participants' recruitment has been described in detail previously [39]. Briefly, the population registry of the city provided the complete list of the Lausanne inhabitants aged $35-75$ years $(n=56,694)$. Subjects were selected using a simple, non-stratified random selection approach. Overall, 6184 participants were included. For the present analysis, 6183 participants had data on at least one of the four measured circulating inflammatory markers.

\section{Analytical method}

Venous blood samples $(50 \mathrm{~mL})$ were drawn in the fasting state between 7 am and noon. Hs-CRP was assessed by immunoassay and latex HS (IMMULITE 1000-High, Diagnostic Products Corporation, LA, CA, USA) with maximum intra- and inter-batch coefficients of variation of $1.3 \%$ and $4.6 \%$, respectively. Serum samples were kept at $-80{ }^{\circ} \mathrm{C}$ before assessment of the other cytokines (IL-6, IL-1 $\beta$ and TNF- $\alpha$ ) and sent in dry ice to the laboratory. Cytokine levels were measured using a multiplexed particle-based flow cytometric cytokine assay [40], a methodology used in other studies [41]. Milliplex kits were purchased from Millipore (Zug, Switzerland). The procedures closely followed the manufacturer's instructions. The analysis was conducted using a conventional flow cytometer (FC500 MPL, BeckmanCoulter, Nyon, Switzerland). The lower detection limit for IL-1 $\beta$, IL-6 and TNF- $\alpha$ was $0.2 \mathrm{pg} / \mathrm{mL}$. There were 2388, 556 and 148 values below lower detection limits for IL-1 $\beta$, IL-6 and TNF- $\alpha$, respectively. A good agreement between signal and cytokine was found within the assay range $\left(R^{2} \geq 0.99\right)$. Intra- and inter-assay coefficients of variation were $15 \%$ and $16.7 \%$ for IL-1 $\beta, 16.9 \%$ and $16.1 \%$ for IL- 6 and $12.5 \%$ and $13.5 \%$ for TNF- $\alpha$, respectively. Repeated measurements conducted in 80 subjects randomly drawn from the initial sample showed very high reproducibility. 


\section{Air pollution data}

The monitoring station is located in Lausanne-CésarRoux, at 530 meters above sea level, next to a slightly ascending inner city transit road (30,000 vehicles per day). The station is about 400 meters away from the University Hospital of Lausanne (CHUV) where the participants' examination took part, always between 7 am and noon. On one side of the road is an open school house yard which favors good mixing of the air. In the close vicinity are exclusively apartment buildings and service companies.

The monitoring data was obtained from the website of Swiss National Air Pollution Monitoring Network (NABEL) [42]. We analyzed data on $\mathrm{PM}_{10}$ as well as outside air temperature, pressure and humidity. Hourly concentrations of $\mathrm{PM}_{10}$ were collected from 1 January 2003 to 31 December 2006, for a total of 1461 days. Data control and quality control were done regularly by the responsible agency. Hourly concentrations were then averaged into 24 hours means (0:00-23:00) as a point estimate of air pollutant levels in the study area. We matched air pollution and meteorological data to each participant's examination day.

\section{Statistical analysis}

We defined as extreme outlier cytokine values ten times higher than the value of the $99^{\text {th }}$ percentile. There was one extreme outlier for IL-1 $\beta$, which was higher than $884 \mathrm{pg} / \mathrm{mL}(\mathrm{p} 99=88.4), 7$ outliers for IL-6, which were higher than 1084 $(\mathrm{p} 99=108.4) \mathrm{pg} / \mathrm{mL}$, and 7 outliers for TNF- $\alpha$ higher than $500 \mathrm{pg} / \mathrm{mL}(\mathrm{p} 99=50.0)$. We excluded those values from the analyses. All values of IL-1 $\beta$, IL- 6 , and TNF- $\alpha$ below the detection level $(0.2 \mathrm{pg} / \mathrm{mL})$, were substituted with a value (0.1) equivalent to half of the lower detection limit as recommended by Uh et al. [43]. We performed sensitivity analyses by setting values which were below the detection limits as missing. The results are shown in the Additional files.

Robust linear regression was used to evaluate the relationship between cytokine inflammatory and $\mathrm{PM}_{10}$. Robust regression is a family of regression methods for data in which non-robust least-squares methods may be biased by outliers or heteroscedasticity. The method we chose for estimation was Huber $M$ estimation. We adjusted all analyses for age, sex, body mass index (BMI, calculated as weight in kilograms/height in meters squared), smoking status, alcohol consumption, diabetes status, hypertension status, education levels, zip code, and statin intake. All data were adjusted for the effects of weather by including temperature, barometric pressure, and season as covariates in the adjusted models, using dummies whenever appropriate. We performed stratified analyses by sex, age group and health status. We arbitrarily defined the healthy group as the ones who did not report, or have, any of the following conditions: diabetes, hypertension, smoking, asthma, allergy, chronic bronchitis, coronary artery disease (myocardial infarction, cardiac catheterization, coronary artery bypass surgery), heart failure, stroke, peripheral vascular disease, as well as any drug taken on a regular basis.

Descriptive statistical analysis used the Wilcoxon rank sum test (for medians). All data analyses were performed using Stata 12.0 software (StataCorp, College Station, TX, USA), and a two-sided significance level of $5 \%$ was used.

\section{Additional files}

Additional file 1: Table S1 Levels of inflammatory markers overall and by selected subgroups. Table S2. Change (and $95 \% \mathrm{Cl}$ ) in inflammatory markers associated with a $10 \mu \mathrm{g} / \mathrm{m} 3$ change in ambient $24 \mathrm{~h}$ average PM10 concentration. Table S3. Association of short-term exposure to $24 \mathrm{~h}$ average PM10 with inflammatory markers on the day of examination, and with 1-day to 6-day lags from adjusted robust regression models $\$$. Table $\mathbf{S 4}$. Associations of short-term exposure to $24 \mathrm{~h}$ average PM10 with inflammatory markers, by selected strata.

\section{Competing interests}

Vincent Mooser was a fulltime employee of GlaxoSmithkline.

\section{Acknowledgements}

The authors express their gratitude to the participants in the Lausanne CoLaus study and to the investigators who have contributed to the recruitment, in particular Yolande Barreau, Anne-Lise Bastian, Binasa Ramic, Martine Moranville, Martine Baumer, Marcy Sagette, Jeanne Ecoffey and Sylvie Mermoud for data collection. The CoLaus study was supported by research grants from GlaxoSmithKline, the Faculty of Biology and Medicine of Lausanne, Switzerland and the Swiss National Science Foundation [grant number 33CSCO-122661]. DaiHua Tsai was supported by National Science Council, Taiwan [grant number NSC100-2917-|-564-009]. Murielle Bochud is supported by the Swiss School of Public Health $+(\mathrm{SSPH}+)$.

\section{Author details}

${ }^{1}$ Institute of Social and Preventive Medicine (IUMSP), Lausanne University Hospital (CHUV), Biopôle 2, Route de la Corniche 10, CH-1010 Lausanne, Switzerland. ${ }^{2}$ Department of Chemistry, National Central University, Jhong-Li 32001, Taiwan. ${ }^{3}$ Department of Medicine, Internal Medicine, CHUV, Lausanne, Switzerland. ${ }^{4}$ Institute for Work and Health (IST), Lausanne, Switzerland.

${ }^{5}$ Department of Genetics, GlaxoSmithKline, Philadelphia, PA, USA.

\section{Authors' contributions}

PV and GW performed the experiments and contributed to acquisition of data. DT, PMV, and MB analyzed the data and interpreted the data. The manuscript was written by DT, NA, and MB and revised critically by VM, MR, FP, and JW. All authors read, corrected and approved the final manuscript.

Received: 30 January 2012 Accepted: 6 July 2012

Published: 6 July 2012

\section{References}

1. Brook RD, Rajagopalan S, Pope CA, Brook JR, Bhatnagar A, Diez-Roux AV, Holguin F, Hong Y, Luepker R, Mittleman MA, et al: Particulate Matter Air pollution and Cardiovascular Disease: An Update to the Scientific Statement from the American Heart Association. Circulation 2010, 121:2331-2378.

2. Samoli E, Peng R, Ramsay T, Pipikou M, Touloumi G, Dominici F, Burnett R, Cohen A, Krewski D, Samet J, Katsouyanni K: Acute effects of ambient particulate matter on mortality in Europe and North America: results from the APHENA study. Environ Health Perspect 2008, 116:1480-1486. 
3. Nawrot TS, Perez L, Kunzli N, Munters E, Nemery B: Public health importance of triggers of myocardial infarction: a comparative risk assessment. Lancet 2011, 377:732-740.

4. Pope CA 3rd: Epidemiology of fine particulate air pollution and human health: biologic mechanisms and who's at risk? Environ Health Perspect 2000, 108(Suppl 4):713-723.

5. Woods A, Brull DJ, Humphries SE, Montgomery HE: Genetics of inflammation and risk of coronary artery disease: the central role of interleukin-6. Eur Heart J 2000, 21:1574-1583.

6. Becker S, Soukup JM, Sioutas C, Cassee FR: Response of human alveolar macrophages to ultrafine, fine, and coarse urban air pollution particles. Exp Lung Res 2003, 29:29-44.

7. Becker S, Mundandhara S, Devlin RB, Madden M: Regulation of cytokine production in human alveolar macrophages and airway epithelial cells in response to ambient air pollution particles: Further mechanistic studies. Toxicol Appl Pharmacol 2005, 207:269-275.

8. Calderon-Garciduenas L, Villarreal-Calderon R, Valencia-Salazar G, Henriquez-Roldan C, Gutierrez-Castrellon P, Torres-Jardon R, Osnaya-Brizuela N, Romero L, Solt A, Reed W: Systemic inflammation, endothelial dysfunction, and activation in clinically healthy children exposed to air pollutants. Inhal Toxicol 2008, 20:499-506.

9. Chuang KJ, Chan CC, Su TC, Lee CT, Tang CS: The effect of urban air pollution on inflammation, oxidative stress, coagulation, and autonomic dysfunction in young adults. Am J Respir Crit Care Med 2007, 176:370-376.

10. Peters A, Frohlich M, Doring A, Immervoll T, Wichmann HE, Hutchinson WL, Pepys MB, Koenig W: Particulate air pollution is associated with an acute phase response in men; results from the MONICA-Augsburg Study. Eur Heart J 2001, 22:1198-1204

11. Riediker M, Cascio WE, Griggs TR, Herbst MC, Bromberg PA, Neas L, Williams RW, Devlin RB: Particulate Matter Exposure in Cars Is Associated with Cardiovascular Effects in Healthy Young Men. Am J Respir Crit Care Med 2004, 169:934-940.

12. Pope CA 3rd, Hansen ML, Long RW, Nielsen KR, Eatough NL, Wilson WE, Eatough DJ: Ambient particulate air pollution, heart rate variability, and blood markers of inflammation in a panel of elderly subjects. Environ Health Perspect 2004, 112:339-345.

13. Sullivan JH, Hubbard R, Liu SL, Shepherd K, Trenga CA, Koenig JQ Chandler WL, Kaufman JD: A community study of the effect of particulate matter on blood measures of inflammation and thrombosis in an elderly population. Environ Health 2007, 6:3.

14. Zeka A, Sullivan JR, Vokonas PS, Sparrow D, Schwartz J: Inflammatory markers and particulate air pollution: characterizing the pathway to disease. Int J Epidemiol 2006, 35:1347-1354.

15. Panasevich $S$, Leander $K$, Rosenlund $M$, Ljungman $P$, Bellander $T$, de Faire $U$, Pershagen G, Nyberg F: Associations of long- and short-term air pollution exposure with markers of inflammation and coagulation in a population sample. Occup Environ Med 2009, 66:747-753.

16. Delfino RJ, Staimer N, Tjoa T, Gillen DL, Polidori A, Arhami M, Kleinman MT, Vaziri ND, Longhurst J, Sioutas C: Air Pollution Exposures and Circulating Biomarkers of Effect in a Susceptible Population: Clues to Potential Causal Component mixtures and mechanisms. Environ Health Perspect 2009, 117:1232-1238.

17. Rückerl $R$, Greven $S$, Ljungman $P$, Aalto $P$, Antoniades $C$, Bellander $T$, Berglind N, Chrysohoou C, Forastiere F, Jacquemin B, et al: Air Pollution and Inflammation (Interleukin-6, C-Reactive Protein, Fibrinogen) in Myocardial Infarction Survivors. Environ Health Perspect 2007, 115:1072-1080.

18. Schwartz J: Air pollution and blood markers of cardiovascular risk. Environ Health Perspect 2001, 109(Suppl 3):405-409.

19. Pekkanen J, Brunner EJ, Anderson HR, Tiittanen P, Atkinson RW: Daily concentrations of air pollution and plasma fibrinogen in London. Occup Environ Med 2000, 57:818-822.

20. Hertel S, Viehmann A, Moebus S, Mann K, Bröcker-Preuss M, Möhlenkamp S, Nonnemacher M, Erbel R, Jakobs H, Memmesheimer M, et al: Influence of short-term exposure to ultrafine and fine particles on systemic inflammation. Eur J Epidemiol 2010, 25:581-592.

21. Steinvil A, Kordova-Biezuner L, Shapira I, Berliner S, Rogowski O: Short-term exposure to air pollution and inflammation-sensitive biomarkers. Environ Res 2008, 106:51-61.

22. Liao D, Heiss G, Chinchilli VM, Duan Y, Folsom AR, Lin HM, Salomaa V: Association of criteria pollutants with plasma hemostatic/inflammatory markers: a population-based study. J Expo Anal Environ Epidemiol 2005, 15:319-328.

23. Diez Roux AV, Auchincloss AH, Astor B, Barr RG, Cushman M, Dvonch T, Jacobs DR Jr, Kaufman J, Lin X, Samson P: Recent exposure to particulate matter and C-reactive protein concentration in the multi-ethnic study of atherosclerosis. Am J Epidemiol 2006, 164:437-448.

24. van Eeden SF, Tan WC, Suwa T, Mukae H, Terashima T, Fujii T, Qui D, Vincent $R$, Hogg JC: Cytokines involved in the systemic inflammatory response induced by exposure to particulate matter air pollutants (PM(10)). Am J Respir Crit Care Med 2001, 164:826-830.

25. Dubowsky SD, Suh H, Schwartz J, Coull BA, Gold DR: Diabetes, obesity, and hypertension may enhance associations between air pollution and markers of systemic inflammation. Environ Health Perspect 2006, 114:992-998.

26. Delfino RJ, Staimer N, Tjoa T, Polidori A, Arhami M, Gillen DL, Kleinman MT, Vaziri ND, Longhurst J, Zaldivar F, Sioutas C: Circulating Biomarkers of Inflammation, Antioxidant Activity, and Platelet Activation Are Associated with Primary Combustion Aerosols in Subjects with Coronary Artery Disease. Environ Health Perspect 2008, 116:898-906.

27. Kido T, Tamagawa E, Bai N, Suda K, Yang HH, Li Y, Chiang G, Yatera K, Mukae $H$, Sin DD, Van Eeden SF: Particulate matter induces translocation of IL-6 from the lung to the systemic circulation. Am J Respir Cell Mol Biol 2011, 44:197-204.

28. Libby P, Ridker PM, Maseri A: Inflammation and Atherosclerosis. Circulation 2002, 105:1135-1143.

29. Ross R: Atherosclerosis - An Inflammatory Disease. N Engl J Med 1999, 340:115-126.

30. Blankenberg $S$, Luc $G$, Ducimetière $P$, Arveiler $D$, Ferrières J, Amouyel $P$, Evans A, Cambien F, Tiret L: on behalf of the PRIME Study Group: Interleukin-18 and the Risk of Coronary Heart Disease in European Men The Prospective Epidemiological Study of Myocardial Infarction (PRIME). Circulation 2003, 108:2453-2459.

31. Ridker PM, Hennekens CH, Buring JE, Rifai N: C-Reactive Protein and Other Markers of Inflammation in the Prediction of Cardiovascular Disease in Women. N Engl J Med 2000, 342:836-843.

32. Yarnell JWG, Patterson CC, Sweetnam PM, Lowe GDO: Haemostatic/ inflammatory markers predict 10-year risk of IHD at least as well as lipids: the Caerphilly collaborative studies. Eur Heart J 2004, 25:1049-1056.

33. Weigand MA, Hörner C, Bardenheuer HJ, Bouchon A: The systemic inflammatory response syndrome. Best Pract Res Clin Anaesthesiol 2004 18:455-475.

34. Wellenius GA, Burger MR, Coull BA, Schwartz J, Suh HH, Koutrakis P, Schlaug G, Gold DR, Mittleman MA: Ambient air pollution and the risk of acute ischemic stroke. Arch Intern Med 2012, 172:229-234.

35. Tamagawa E, Bai N, Morimoto K, Gray C, Mui T, Yatera K, Zhang X, Xing L, Li Y, Laher I, et al: Particulate matter exposure induces persistent lung inflammation and endothelial dysfunction. Am J Physiol Lung Cell Mol Physiol 2008, 295:L79-L85.

36. Brauner EV, Forchhammer L, Moller P, Simonsen J, Glasius M, Wahlin P, Raaschou-Nielsen O, Loft S: Exposure to ultrafine particles from ambient air and oxidative stress-induced DNA damage. Environ Health Perspect 2007, 115:1177-1182.

37. Vigushin DM, Pepys MB, Hawkins PN: Metabolic and scintigraphic studies of radioiodinated human $\mathrm{C}$-reactive protein in health and disease. $J$ Clin Investig 1993, 91:1351-1357.

38. Putaud J-P, Raes F, Van Dingenen R, Brüggemann E, Facchini MC, Decesari S, Fuzzi S, Gehrig R, Hüglin C, Laj P, et al: A European aerosol phenomenology-2: chemical characteristics of particulate matter at kerbside, urban, rural and background sites in Europe. Atmos Environ 2004, 38:2579-2595.

39. Firmann M, Mayor V, Vidal P, Bochud M, Pecoud A, Hayoz D, Paccaud F, Preisig M, Song $K$, Yuan $X$, et al: The CoLaus study: a population-based study to investigate the epidemiology and genetic determinants of cardiovascular risk factors and metabolic syndrome. BMC CardiovasC Disord 2008, 8:6.

40. Vignali DA: Multiplexed particle-based flow cytometric assays. J Immunol Methods 2000, 243:243-255.

41. von Kanel R, Begre S, Abbas CC, Saner H, Gander ML, Schmid JP: Inflammatory biomarkers in patients with posttraumatic stress disorder caused by myocardial infarction and the role of depressive symptoms. Neuroimmunomodulation 2010, 17:39-46. 
42. NABEL: National Air Pollution Monitoring Network. http://www.bafu.admin.ch/ luft/luftbelastung/index.html?lang=en.

43. Uh H-W, Hartgers F, Yazdanbakhsh M, Houwing-Duistermaat J: Evaluation of regression methods when immunological measurements are constrained by detection limits. BMC Immunol 2008, 9:59.

doi:10.1186/1743-8977-9-24

Cite this article as: Tsai et al.: Effects of particulate matter on

inflammatory markers in the general adult population. Particle and Fibre Toxicology 2012 9:24.

Submit your next manuscript to BioMed Central and take full advantage of:

- Convenient online submission

- Thorough peer review

- No space constraints or color figure charges

- Immediate publication on acceptance

- Inclusion in PubMed, CAS, Scopus and Google Scholar

- Research which is freely available for redistribution 